Eur. J. Clin. Chem. Clin. Biochem.

Vol. 32, 1994, pp. 595-598

(c) 1994 Walter de Gruyter \& Co.

Berlin · New York

\title{
Affinity Chromatographic Method for the Extraction of Ocytocin from Human and Rat Plasma
}

\author{
By Angela Török ${ }^{1}, M$. Vecsernyés ${ }^{2}$ and B. Penke \\ 1 Szent-Györgyi Albert Orvostudományi Egyetem, Orvosi Vegytani Intézete, Szeged, Hungary \\ 2 I. Belklinika, Önálló Endokrinológiai Osztály és Kutató Laboratórium, Szeged, Hungary
}

(Received January 3/April 26, 1994)

Summary: A procedure based on affinity chromatography for the extraction of ocytocin is described. Ocytocin antibody, covalently attached to a magnetizable iron suspension, retains its ability to bind ocytocin from blood plasma. The conjugate can be reused several times. Recovery of ocytocin was $60-70 \%$, and the detection limit for the extraction assay was about $1 \mathrm{pg}$ per tube. The specificity of the extraction method was characterized by HPLC/ RIA on specimens extracted from blood plasma. The extracted material was found to be chomatographically identical with the reference ocytocin preparation. Comparison of RIA data for the same samples extracted by immunoextraction $(y)$ and adsorption $(x)$ showed a linear regression of $y=0.83 x+2.12, r=0.81, n=17$.

\section{Introduction}

The neurohypophysial hormone, ocytocin, has various functions. It acts as a peripheral hormone, as a neuropeptide in the brain, and as a paracrine substance in several tissues. As a hormone, it regulates parturition and lactation; as a neuropeptide, it participates in memory processes, maternal and sexual behaviour, and the development of tolerance and addiction to narcotic drugs; as a paracrine factor, it plays a role in various peripheral organs (e. g. the ovary). Its biological importance stimulated various groups to develop methods for measurement of the hormone. Its basal circulating levels in the blood are low. Most of the RIA determinations involve extraction techniques, prior to the assay of ocytocin in the plasma $(1-5)$. Extraction is necessary to eliminate non-specific interfering substances in the plasma, but the procedures are time-consuming and may involve significant and variable lôssses of ocytocin.

Our aim was to study the ocytocin extraction based on affinity chromatography with magnetizable iron particles. For this purpose, the ocytocin antibody was covalently attached to the surface of an iron suspension, and its ability to bind and extract ocytocin from human and rat plasma was examined. Additionally, the reusability of the iron-antibody conjugate was investigated.

\section{Materials and Methods}

Human blood was collected in EDTA-containing tubes at 8-9 a. m. from the antecubital vein of healthy subjects in the supine position. After centrifugation for $10 \mathrm{~min}$ at $1500 \mathrm{~g}$ and $4^{\circ} \mathrm{C}$, the plasma was collected in polystyrene tubes and stored at $-70^{\circ} \mathrm{C}$ until extraction.

Adult male Wistar rats weighing $180-230 \mathrm{~g}$ were used. Blood samples were obtained from the trunks of decapitated rats between 8 and 10 a.m., collected in polystyrene tubes containing EDTA in isotonic saline, maintained on an ice-bath, subsequently centrifuged at $2000 \mathrm{~g}$ for $10 \mathrm{~min}$ at $4^{\circ} \mathrm{C}$ and stored at $-70^{\circ} \mathrm{C}$ until extraction.

\section{Mạterials}

The sources of materials were as follows: synthetic ocytocin (Bachem, Bubendorf, Switzerland), N-terminal Biomag magnetic particles (Advanced Magnetics, Inc., Cambridge, MA), bis-succinimidyl suberate (Serva, Heidelberg, Germany), trifluoroacetic acid (Fluka, Germany), methanol (HPLC grade), Veronal-Na (Merck, Germany), bovine serum albumin, $L$-cystine (Sigma, St. Louis, USA). All other chemicals were of analytical grade.

The RIA buffer consisted of $20 \mathrm{mmol}$ of Veronal- $\mathrm{Na}, 10 \mathrm{mmol}$ of EDTA- $\mathrm{Na}_{2}, 0.14 \mathrm{~mol}$ of $\mathrm{NaCl}, 5 \mathrm{~g}$ of bovine serum albumin and $0.01 \mathrm{~g}$ of $L$-cystine per litre, $\mathrm{pH}=8$.

\section{Antibody preparation and purification}

The ocytocin antiserum against ocytocin- $\varepsilon$-aminocaprilyl bovine thyroglobulin was produced in rabbit (6). 
The ocytocin antibody was purified before use in the coupling procedure. The IgG fraction of the native antiserum was precipitated by dropwise addition of an equal volume of $360 \mathrm{~g} / 1$ sodium sulphate. After centrifugation, the precipitate was washed with $18 \mathrm{~g} / 1$ sodium sulphate. The pellet was dissolved in $0.03 \mathrm{~mol} / \mathrm{l} \mathrm{HCl}$, and $0.03 \mathrm{~mol} / \mathrm{l} \mathrm{NaOH}$ was added dropwise until opalescence and precipitation occurred. The mixture was centrifuged at $2000 \mathrm{~g}$ for 15 min at $4^{\circ} \mathrm{C}$, and the resulting pellet was dissolved in isotonic saline and dialysed against distilled water for 2 days at $4{ }^{\circ} \mathrm{C}$. The dialysed fraction was lyophilized.

\section{Methods}

\section{Antibody coupling to magnetic particles}

The coupling procedure was performed according to the bis-succinimidyl suberate active ester method (7). Lyophilized (10-20 $\mathrm{mg}$ ) ocytocin antibody was coupled to $1 \mathrm{ml}$ of magnetic suspension. The resulting antibody-coated particles were washed three to four times with $0.03 \mathrm{~mol} / 1 \mathrm{HCl}$, followed by $0.03 \mathrm{~mol} / 1 \mathrm{NaOH}$, then stored in assay buffer containing $0.2 \mathrm{~g} / 1 \mathrm{NaN}_{3}$ (sodium azide) as preservative. After immunoextraction, the sedimented magnetic iron conjugate was washed twice with $500 \mu$ of RIA buffer, made up with assay buffer (containing $0.2 \mathrm{~g} / \mathrm{l}$ sodium azide) to the final volume (representing a two or fourfold dilution of the conjugate), then stored at $4^{\circ} \mathrm{C}$.

\section{Procedures}

\section{Immunoextraction}

One $\mathrm{ml}$ of human plasma was mixed with $200 \mu \mathrm{l}$ of magnetic suspension diluted with assay buffer, and rotated end-over-end for 3 hours at $4{ }^{\circ} \mathrm{C}$. To separate the particle-bound fraction, the tubes were placed on a magnetic rack, the particles were sedimented and the supernatant was discarded. The magnetic suspension was washed twice with $500 \mu \mathrm{l}$ of assay buffer. The ocytocin was then eluted from the magnetic iron conjugate with $400 \mu \mathrm{l}$ of methanol/ water $(80+20$, by vol.) containing $1 \mathrm{ml} / \mathrm{l}$ trifluoroacetic acid. An aliquot $(300 \mu \mathrm{l})$ of the supernatant was dried under a nitrogen stream. The residue was dissolved in $225 \mu \mathrm{l}$ of RIA buffer and analysed in duplicate (6).

Standard concentrations of ocytocin ( $0.8-100 \mathrm{pg}$ per tube) were prepared in assay buffer, or in "ocytocin-free plasma" and immunoextracted. Peptide-free plasma was made from pooled plasma samples, pretreated with activated charcoal, centrifuged, and purified on Sep-Pak cartridge.

\section{Adsorption method}

The method was based on that described earlier (8). Lichroprep Si60 $(20 \mathrm{mg})$, distilled water $(100 \mu \mathrm{l})$ and $1 \mathrm{~mol} / \mathrm{l} \mathrm{HCl}(400 \mu \mathrm{l})$ were added to $2 \mathrm{ml}$ of blood plasma in polypropylene tubes. The mixture was agitated for 30 min then centrifuged. The supernatant was discarded, the pellet washed twice with distilled water, and the immunoreactive material eluted with acetone/water $(60+40$, by vol.), evaporated and assayed.

\section{Radioimmunoassay}

A relatively sensitive in-house RIA was set up (6).

The ocytocin antibody affinity constant was $3.7 \times 10^{9} \mathrm{~mol} / \mathrm{l}$. Cross reaction with related peptides: ocytocin 100 , vasotocin 0.11 , ocypressin 92.7, ocytocin o $_{1-8} 3.26$, arginine-vasopressin $0.11 \%$, pressionic acid, melanostatin and ocytocin $4-8$ less than $0.05 \%$. $\left.{ }^{125} \mathrm{I}\right]$ Ocytocin was prepared by the method of Hunter \& Greenwood (9) and purified by two-step reverse-phase chromatography (10). The specific radioactivity was about $70.3 \mathrm{TBq} / \mathrm{mmol}$.
For the RIA, $50 \mu$ l of ocytocin antibody (at a final dilution of $1: 70000$ ) were added to $100 \mu$ of sample or standard, then incubated for $24 \mathrm{~h}$ at $4{ }^{\circ} \mathrm{C}$, followed by addition of iodine-labelled ocytocin $(10000$ counts/min in $50 \mu \mathrm{l})$. After incubation for a further $24 \mathrm{~h}$, the bound and free conjugates were separated by adding $50 \mu \mathrm{l}$ of horse serum and $500 \mu \mathrm{l}$ of polyethyleneglycol in water, $300 \mathrm{~g} / \mathrm{l}$. After centrifugation at $1500 \mathrm{~g}$ for 15 minutes, the radioactivity of the pellet was measured on a Wiżdrd automatic gamma counter (Wallac Oy, Finland), with subsequent calculation via the Multicalc program (Wallac Oy, Finland).

\section{High performance liquid chromatography}

The procedure was performed as described earlier (11). Eluates of 39-39 immunoextracted human or rat plasma samples were pooled and evaporated. The residues were dissolved in methanol/water $(30+70$, by vol.) containing $1 \mathrm{ml} / 1$ trifluoroacetic acid. A Knauer HPLC system with gradient elution was used to characterize the ocytocin-like immunoreactivity. Aliquots of the dissolved samples were loaded onto a Si-100-S RP-C18 column $(5 \mu \mathrm{m}, 260 \times 4.6$ $\mathrm{mm}$; BST, Budapest, Hungary) and eluted in a gradient system of aqueous methanol, volume fractions $0.3-0.6$ containing $1 \mathrm{ml} / \mathrm{l}$ trifluoroacetic acid. To avoid contamination, specimens were run in the sequence: blank, pooled human or rat samples, and finally standard ocytocin $(0.5 \mathrm{ng})(12)$. The flow rate was $1.0 \mathrm{ml} / \mathrm{min}$.

The eluted HPLC fractions were collected at 1-min intervals for up to $50 \mathrm{~min}$ and subjected to RIA (figs. la, b).

\section{Results}

The purified ocytocin antibody was coupled to N-terminal magnetizable particles by the active ester method. To exclude interference from endogenous ocytocin, the conjugate was purified. Pretreatment of the antibody and repeated washing of the iron-antibody conjugate led to an increase in the binding and a reduction of the nonspecific binding to $3 \%$.

The ocytocin binding capacity of the antibody-coupled particles was determined by adding iodine-labelled ocytocin to serial dilutions of particle suspension. The binding of the ocytocin tracer for the two- or fourfold diluted suspension was 85 and $78 \%$, respectively. The standard curve was corrected for the ocytocin-free plasma, to eliminate extraction losses and procedural errors.

The efficiency of the immunoextraction was determined by adding different amounts of ocytocin to the rat plasma pool. The following recoveries were found: 50 $\mathrm{ng} / 161.7 \pm 6.4 \%, 25 \mathrm{ng} / 171.2 \pm 5.2 \%$ and $12.5 \mathrm{ng} / 1$ $74.2 \pm 7.6 \%$, respectively, $(x \pm S E M, n=5)$.

Intra- and inter-assay coefficients of variation determined on pooled rat plasma specimens at a concentration of $12.1 \pm 0.8 \mathrm{ng} / \mathrm{l}$ were 7.9 and $13.9 \%(\mathrm{n}=6)$, and at $46.7 \pm 1.8 \mathrm{ng} / 15.3$ and $10.1 \%(n=6)$, respectively. The detection limit of the assay after immunoextraction was $1 \mathrm{pg}$ per tube.

The basal concentration in rat plasma was found to be $15.28 \mathrm{ng} / \mathrm{l} \pm 0.84 \mathrm{SEM} ; \mathrm{n}=6$. 
The residual extracted suspension was washed with RIA buffer, made up to final volume and stored. Repeated use of the conjugate was investigated. For three successive immunoextractions of plasma the following ocytocin values were obtained: $15.9 \pm 4.0,17.2 \pm 3.4$ and 14.6 $\pm 3.0 \mathrm{ng} / \mathrm{l}, \mathrm{n}=6$.

In HPLC, a major proportion of the ocytocin immunoreactivity in both the human and rat plasma samples migrated together with the reference ocytocin preparation (figs. 1a, b).

To assess the accuracy of the immunoextraction, the results from immunoextracted human samples were compared with those after adsorption extraction.

Regression of the results gave the equation $\mathrm{y}=0.83 \mathrm{x}$ $+2.12, \mathrm{r}=0.81, \mathrm{n}=17$, SE slope 0.15 , Yse 1.28.
After adsorption extraction

females

$3.9 \pm 0.6$ SE, n. s., $n=11$

males

$4.1 \pm 0.9$ SE, n. s., $n=6$

After immunoextraction

females $\quad 5.7 \pm 0.6 \mathrm{SE}, \mathrm{n} . \mathrm{s} ., \mathrm{n}=11$

males $\quad 5.2 \pm 0.6 \mathrm{SE}, \mathrm{n}$. s., $\mathrm{n}=6$

(two way Anova, followed by Scheffe's rank test)

\section{Discussion}

A sensitive RIA is dependent on the production of a highly specific and high-affinity antiserum with a radiolabelled tracer of adequate specific activity. These properties are necessary for direct measurement without prior extraction $(13,14)$. Many techniques have been
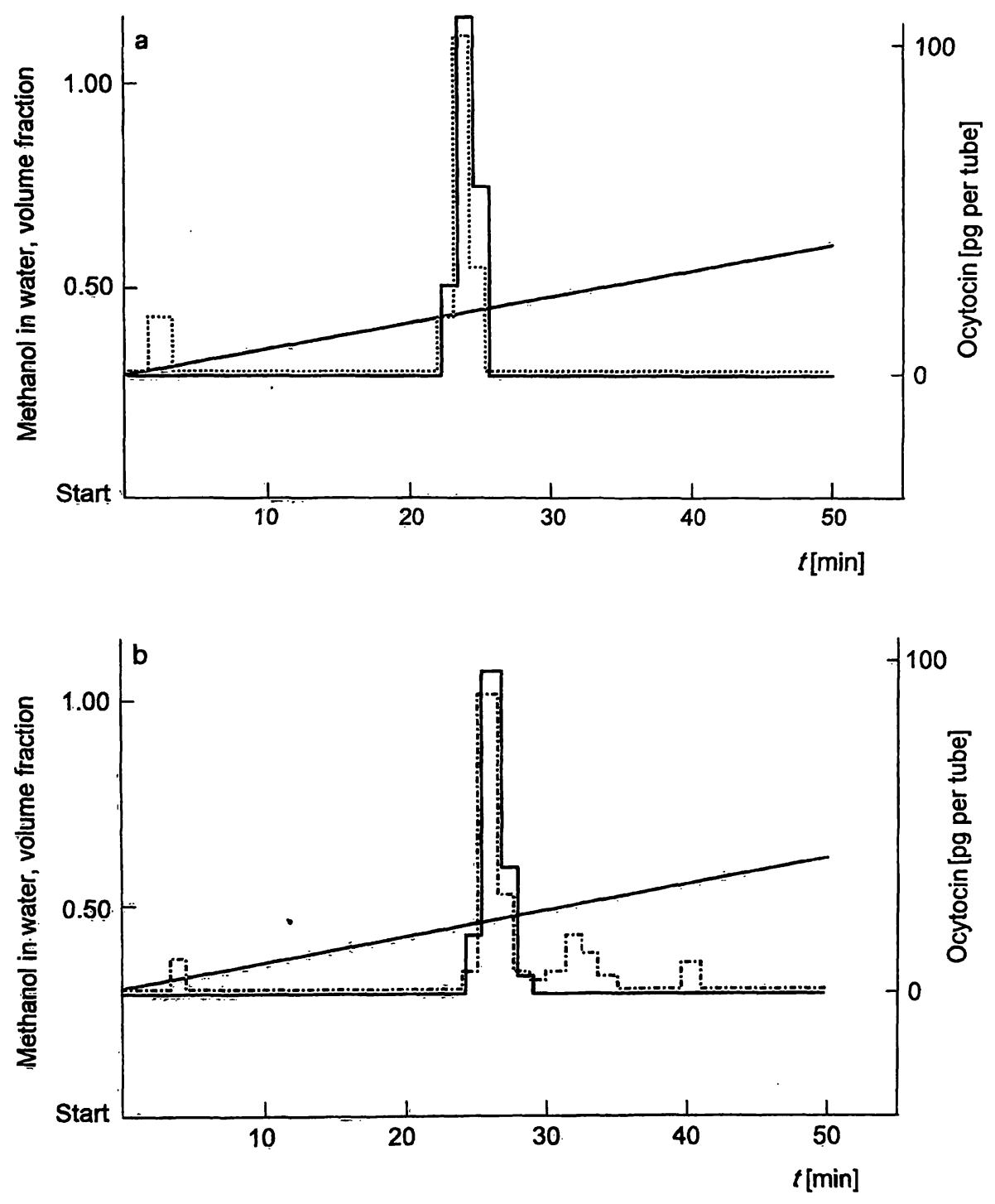

Fig. 1a, b Elution profile of immunoextracted human and rat plasma samples. The elution was performed with a gradient system of aqueous methanol containing $1 \mathrm{ml} / 1$ trifluoroacetic acid, and fractions were radioimmunoassayed for ocytocin. The immunoreactive material was eluted at the same position as the reference ocytocin (-), in a) human $(\cdots)$ and b) rat $(\cdots \cdots)$ plasma extracts. 
described for the extraction and concentration of ocytocin from plasma. Most methods are based on simple physicochemical techniques. An acid-ethanol mixture has been used to precipitate proteins from blood samples (15), while other, similar procedures involve the use of acetone $(16,17)$. Another type of extraction procedure involves the adsorption of ocytocin onto particulate materials such as Fuller's earth or glass beads $(4,18$, 19). The main disadvantage of these methods is that the procedures are non-specific, often work better from acidified plasma and display mediocre recovery rates. The Sep-Pak mini cartridge $(20,21)$, and an affinity extraction method (22) give better results.

The HPLC results demonstrated that the immunoreactive ocytocin is physicochemically identical to the corre= sponding synthetic molecule. Slightly higher plasma levels of ocytocin measured in the present study in comparison with the adsorption method or with other reports could have been due to certain methodological variations.

Repeated use of the washed antibody-iron conjugate appears promising. It seems that the recovery after several washing or elution steps is reproducible. The weakly bound peptides or proteins can readily be removed.

In conclusion, we have set up a new and specific method based on affinity chromatography for the extraction of ocytocin from blood plasma samples.

\section{Acknowledgement}

This study was supported by the Hungarian Foundation for Scientific Research (OTKA Grant No. 6223). The skilful technical assistance of Mrs Györgyi Vorindám is appreciated.

\section{Referencès}

1. Leake, R. D., Waters, C. B., Rubin, R. T., Buster, J. E. \& Fisher, D. A. (1983) Oxytocin and prolactin responses in long term breast feeding. Obstet. Gynecol. 62, 565-568.

2. Weitzman, R. E., Leake, R. D., Rubin, R. T. \& Fisher, D. A. (1980) The effect of nursing on neurohypophysial hormone and prolactin secretion in human subjects. J. Clin. Endocrinol. Metab. 51, 836-839.

3. Amico, J. A., Seif, S. M. \& Robinson, A. G. (1981) Oxytocin in human plasma: Correlation with neurophysin and stimulation with estrogen. J. Clin. Endocrinol. Metab. 52, 988-993.

4. Dawood, M. Y., Raghavan, K. S. \& Pociask, C. (1978) Radioimmunoassay of oxytocin. J. Endocrinol. 76, 261-270.

5. Kumaresan, P., Anandarangam, P. B., Diazon, W. \& Vasicka, A. (1974) Plasma oxytocin levels during human pregnancy and labour as determined by radioimmunoassay. J. Obstet. Gynaecol. 119, 215-223.

6. Vecsernyés, M., Török, A., Jójárt, I., Laczi, F., Penke, B. \& Julesz, J. (1994) Specific radioimmunoassay of oxytocin in rat plasma. Endocr. Regul. submitted for publication.

7. Török, A. \& Penke, B. (1991) Atrial natriuretic peptide assayed after immunoextraction with magnetic iron particles. Clin. Chem. 37, 1769-1773.

8. Dogterom, J., Van Wimersma Greidanus, Tj. B. \& Swaab, D. F. (1977) Evidence for release of vasopressin and oxytocin into cerebrospinal fluid: Measurement in plasma and CSF of intact and hypophysectomized rats. Neuroendocrinology 24, 108118.

9. Greenwood, F. C., Hunter, W. M. \& Glover, J. S. (1963) The preparation of ${ }^{131}$ I-labelled human growth hormone of high specific radioactivity. Biochem. J. 89, 114-123.

10. Janáky, T., Tóth, G., Penke, B., Koväcs, K. \& László, F. A. (1982) Iodination of peptide hormones and purification of iodinated peptides. J. Liquid. Chromatogr. 5, 1499-1507.

11. Vecsernyés, M., Jójárt, I., Pepó, J. \& Laczi, F. (1990) Characterization of oxytocin immunoreactivity in human sympathetic paravertebral ganglia. Brain Research 522, 325-326.

12. Fischman, A. J., Kastin, A. J. \& Graf, M. V. (1984) HPLC shadowing: Artifacts in peptide characterization monitored by RIA. Peptides 5, 1007-1010.

13. Burd, J. M., Weightman, D. R. \& Baylis, P. H. (1985) Solid phase radioimmunoassay for direct measurement of human plasma oxytocin. J. Immunoassay 6, 227-243.

14. Robinson, I. C. A. F. (1980) The development and evaluation of a sensitive and specific radioimmunoassay for oxytocin in unextracted plașma. J. Immunoassay $1,323-347$.

15. Bisset, G. W. \& Walker, J. M. (1954) Assay of oxytocin in blood. J. Physiol. 126, 588-595.

16. Bashore, R. A. (1972) Studies concerning a radioimmunoassay for oxytocin. Amer. J. Obstetr. Gynecol. 113, 488-496.

17. Lang, R. E., Heil, J. W. E., Ganten, D., Hermann, K., Rascher, W. \& Unger, T. (1983) Effects of lesions in the paraventricular nucleus of the hypothalamus on vasopressin and oxytocin contents in brainstem and spinal cord of rat. Brain Research 260 , $326-334$.

18. Chard, T., Boyd, N. R. H., Forsling, M. L., McNeilly, A. S. \& Landon, J. (1970) The development of a radioimmunoassay for oxytocin from plasma and its measurement during parturition in human and goat blood. J. Endocrinol. 48, 223-234.

19. Boyd, N. R. H., Jackson, D. B., Hollingsworth, S., Forsling, M. L. \& Chard, T. (1972) The development of a radioimmunoassay for oxytocin: The extraction of oxytocin from urine and determination of the excretion rate for exogenous and endogenous oxytocin in human urine. J. Endocrinol. 52, 59-67.

20. Schams, D. (1983) Oxytocin determination by radioimmunoassay III. Improvement to subpicogram sensitivity and application to blood levels in cyclic cattle. Acta Endocrinol. (Copenh.) $103,180-183$.

21. Ho, M-L. \& Lee, J-N. (1992) Ovarian and circulating levels of oxytocin and arginine vasopressin during the estrous 'in the rat. Acta Endocrinol: (Copenh.) 126, 530-534.

22. Robinson, I. C. A. F. \& Walker, J. M. (1979) Extraction of small amounts of oxytocin from biological fluids by means of agarose-bound neurophysin. J. Endocrinol. 80, 191-202.

Angela Török
A. Szent-Györgyi Medical University
Department of Medical Chemistry
Dóm tér 8
H-6720 Szeged
Hungary

Angela Török

Dóm tér 8

Hungary 